\title{
Design of Asset Collection Information System Based on Website
}

\author{
Dwi Edi Sadharma * \\ Information Technology Faculty, STMIK Abulyatama Aceh \\ Email: dwiedisadharma@gmail.com
}

Received: 16 January 2021; Accepted: 21 March 2021; Published: 1 April 2021

\begin{abstract}
The Asset Management Information System is one of the data processing activities at the Aceh Plantation Office, to obtain information about assets that is more targeted and easy to obtain. In writing this thesis, the author only discusses the problem of designing a web-based Asset Management Information System at the Aceh Plantation Service. The research objective was to identify and design a web-based Asset Management Information System at the Aceh Plantation Service and the Asset Management Information System Design using PHP and MySQL. The collection of data needed in writing this thesis is obtained by two methods, namely literature study related to library books and other scientific works, field studies by conducting interviews, and direct observation of objects related to this thesis. Asset Management Information System is carried out by one of the administrative staff in the field of administration to record and input asset data. From the results of the study, it can be concluded that the Asset Management Information System at the Aceh Plantation Office has followed procedures and uses a computer with HTML, CSS, JQuery, JSON, PHP, and MySQL programming languages as the database.
\end{abstract}

Index Terms: Design; Information Systems; Asset Data Collection; Website.

\section{Introduction}

Information system has now become a very important commodity [1,2]. Some even say that we are already in an "information-based society" [3, 4]. The ability to access and provide very fast and accurate information is essential for an organization [4,5], both in the form of university corporate organizations [6], government agencies [7, 8], and individuals [9]. This has been made possible by the rapid development in the field of computer technology. Especially in asset data collection. Assets here are assets or objects consisting of immovable objects and movable objects, both tangible and intangible, which are included in company assets $[10,11]$. The existence of assets really helps the company in carrying out its activities. However, if in practice the assets are not properly maintained and managed, it will be able to hinder the activities of the company itself. So it is necessary to have asset management that can manage all assets owned.

Physical asset management has not been implemented much, many companies consider physical asset management as asset list management [12]. Whereas asset management is not only about compiling a list of assets but also concerning the evaluation and valuation of assets which can enable the system to control and handle changes in asset data quickly [13]. Asset management also looks for ways to optimize activities and programs to meet service level standards. Management development is based on gathering and analyzing key information regarding asset condition, performance, costs, service life, risk costs, and treatment options.

Given the importance of fixed assets for an organization, fixed asset management is required. Asset management is the process of managing, planning, and controlling the acquisition, use, maintenance, repair, or disposal of tangible assets (fixed assets) to optimize their potential uses and to minimize associated risks and costs during their useful life by using intangible assets such as supporting applications. decision making and business processes.

The Aceh Plantation Office uses the Microsoft Exel application to record asset data as well as email and fax as a means of communication and sending data, but this application still has many shortcomings in terms of information dissemination. The problem that often arises is the loss of asset data, especially if assets are only labeled. So that sometimes the asset data holder is not known, so an information system is needed for asset data collection at the Aceh Plantation Service. This system includes a request process, adding assets, a process for procuring assets, a process for recording and monitoring assets. 


\section{Research Method}

To assist in the preparation of this research, it is necessary to have a clear framework in stages. This framework represents the steps that will be taken in solving the problems to be discussed. The research framework used is as shown in Figure 1.

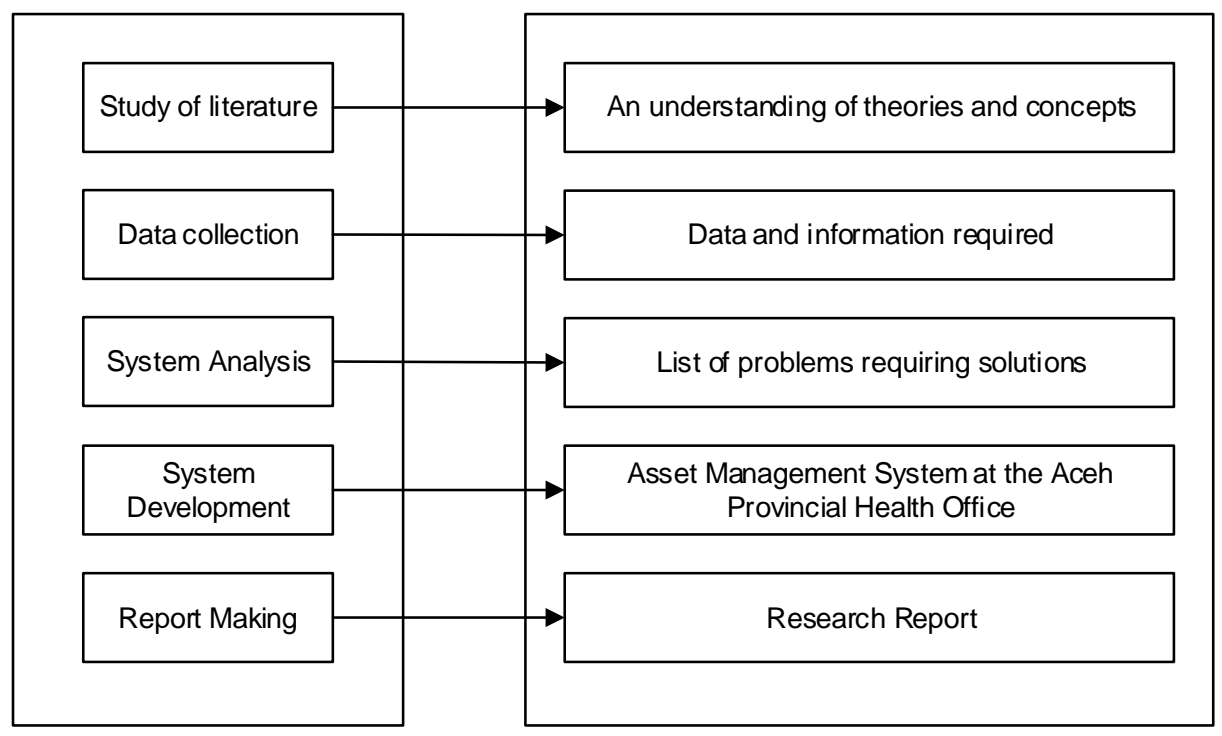

Fig.1. Research Framework

Based on the research framework described above, the discussion of each stage in the research can be described as follows:

a) Literature Study

At this stage, the search for theoretical foundations obtained from various books and the internet is also carried out to complement the vocabulary of concepts and theories, so that they have a good and appropriate foundation and science.

b) Data Collection

At this stage, the data collection process was carried out using interview and observation methods to observe and analyze the ongoing asset data collection process at the Aceh Provincial Plantation Office so that the data and information needed by the researchers were obtained.

c) System Analysis

At this stage, problem identification is carried out in the running system. Thus, it is hoped that researchers can find obstacles and problems that occur in the asset data collection process at the Aceh Provincial Plantation Office so that researchers can find solutions to these problems.

d) System Development

At this stage, system development is carried out using the waterfall model.

e) Reporting

At this stage, reports are prepared based on research results using primary and secondary data collection techniques so that they become research reports that can provide a complete picture of the system being built.

In this study, the authors used several field research methods, namely by obtaining data directly from the research site so that the data required in this thesis were the real data obtained when the research was carried out. As for the research data collection, the writer uses the following collection methods:

a) Interview, namely data collection by conducting direct interviews with related parties in order to obtain information on the problems faced,

b) Observation, namely direct observation of the current system mechanism at the Plantation Office of Aceh Province. 
The current Inventory Asset Data Procedure is as follows

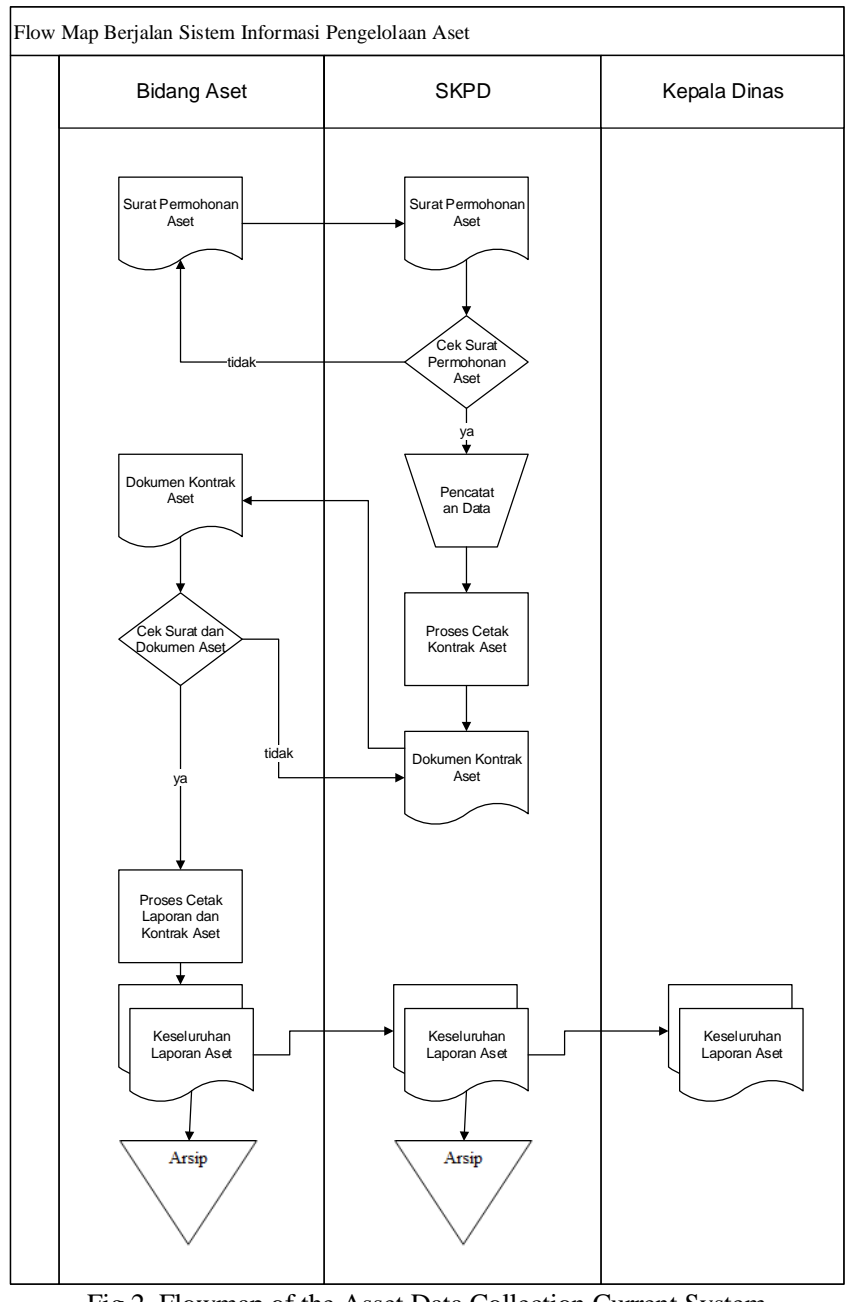

Fig.2. Flowmap of the Asset Data Collection Current System

System analysis is the stage after analysis of the system development cycle which is defined from the functional requirements of preparation for implementation design which describes how a system is formed, which can be in the form of drawing, designing, and sketching, or arranging several separate elements into a single unit. intact and functioning also concerns the configuration of hardware and software components [14].

At this stage, it is explained about making a sketch or arrangement of several separate elements into one unified, functional and useful unit. System design is divided into 2, namely conceptual design or general design or logical design and detailed design or physical design. The general design that will be applied aims to provide a general overview to the user about the system to be built. The general design identifies the components of the information system to be designed in detail. This design stage will begin with the creation of the proposed flowchart.

The design of the Asset Data Collection Information System at the Aceh Plantation Office will produce a product in the form of an application program that can handle data processing such as space and inventory which will be given to the Head of the Aceh Plantation Service which will be used as consideration for decision making. In addition, the system can process all input data in the system and then produce an output that suits your needs, such as asset data collection and reports related to the Banda Aceh Regional Financial and Asset Data Collection Information System (DPKAD).

Software development is the newest industry, in industry, development, and growth are really needed to get better. Software development at a company is more than just writing code. Collaboration with other teams and team members with various specialized knowledge is an additional step in documenting the software development process [15].

The Linear Sequential Model often called the Waterfall Model, is the oldest and most widely used software engineering paradigm. This model proposes a systematic and partial software development approach starting at the level and progress of the system throughout the analysis, design, code, testing, and maintenance $[14,16]$. 


\section{Analysis}

\section{Design}

\section{Test}

\section{Operate}

Fig.3. Stages in the Waterfall Model

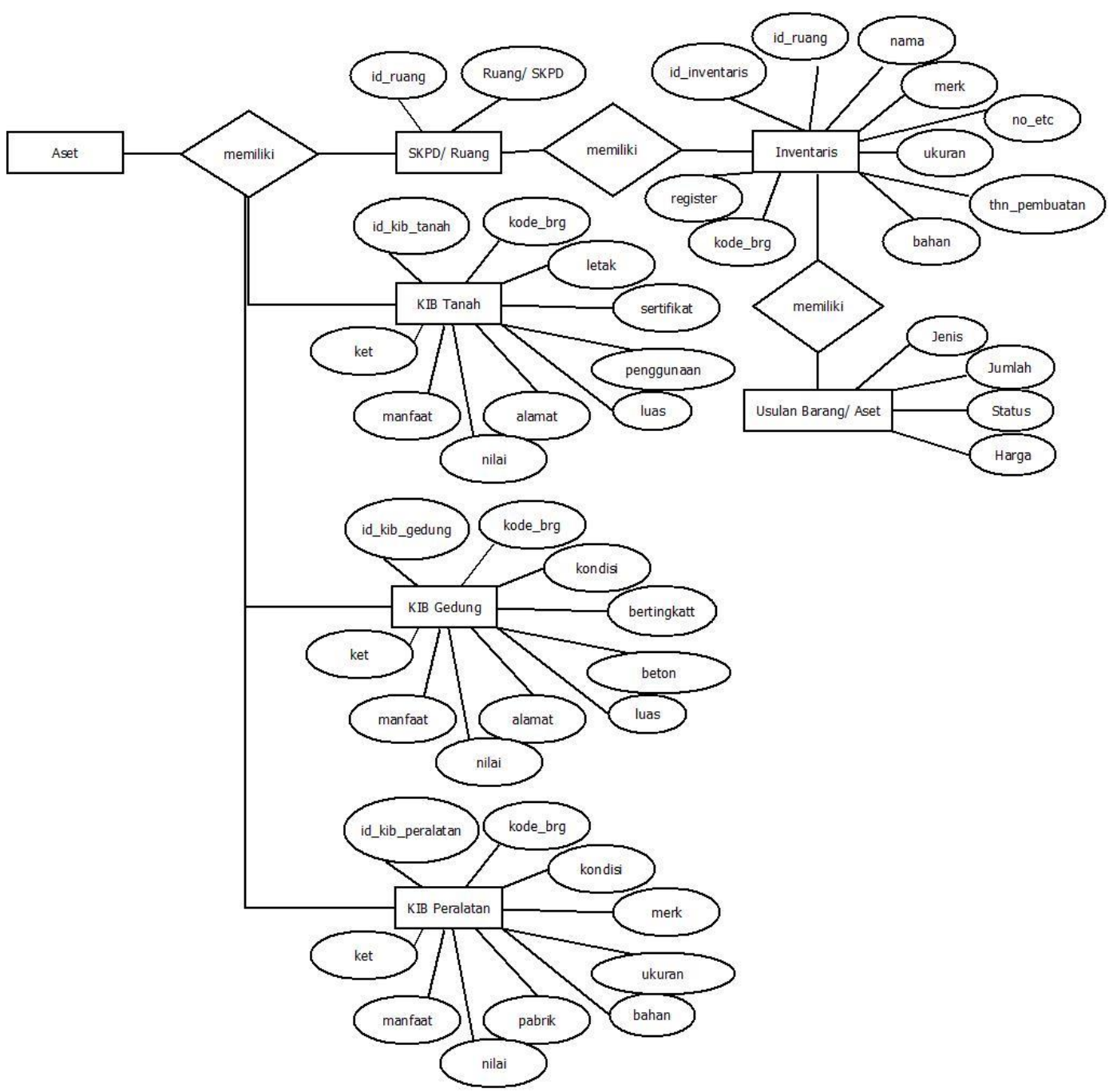

Fig.4. Entity Relationship Diagram

By making a context diagram of the system, the structure of this approach describes the system in general which will then be broken down into more detailed parts. The following image is a diagrammatic context of the asset collection. 


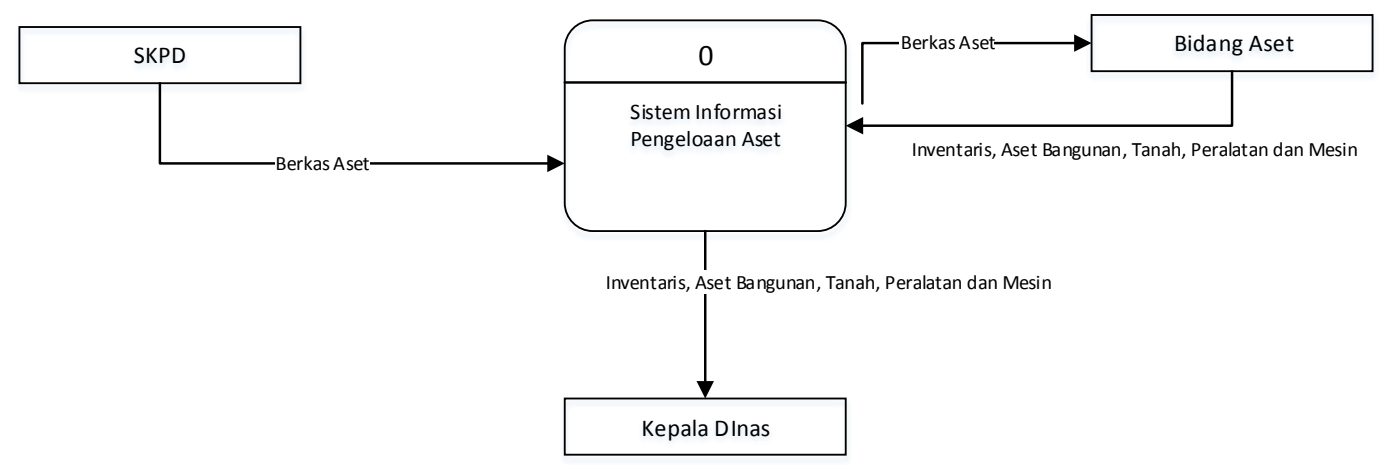

Fig.5. Context Diagram Design

In this Context Diagram image, the asset document data is taken or obtained from the SKPD and then the asset field processes the data for storage. The data that has been entered or inputted can be seen by the Head of Service on the system. Meanwhile, the process of data collection can be seen in the following figure.

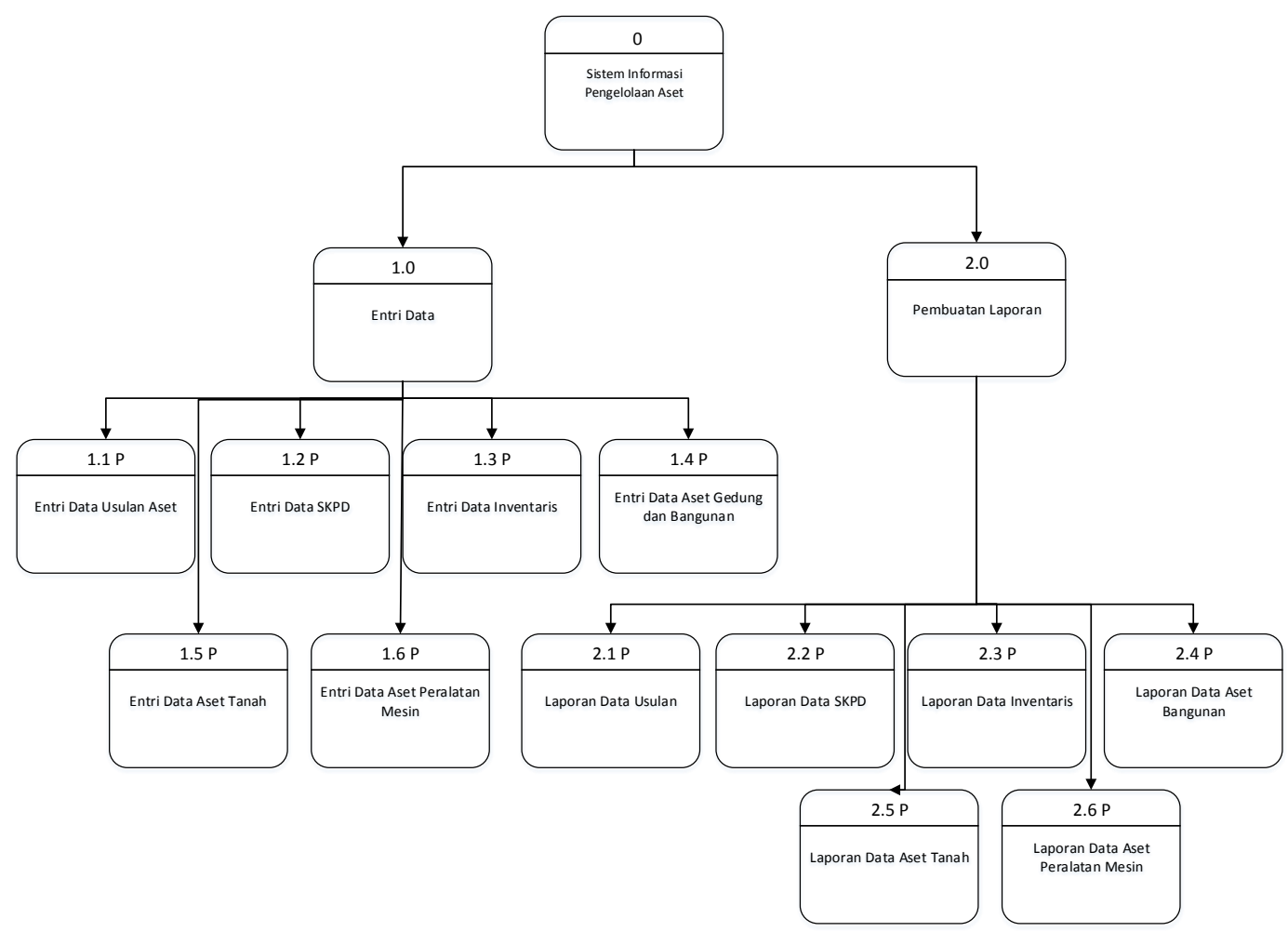

Fig.6. Tiered Diagram

Based on Figure 6, it can be seen that in each asset data collection at the Plantation Office of Aceh Province, there are three processes. The three processes are data entry input, asset verification process and report preparation. For more details, from one process to another can be seen in Figure 7. 


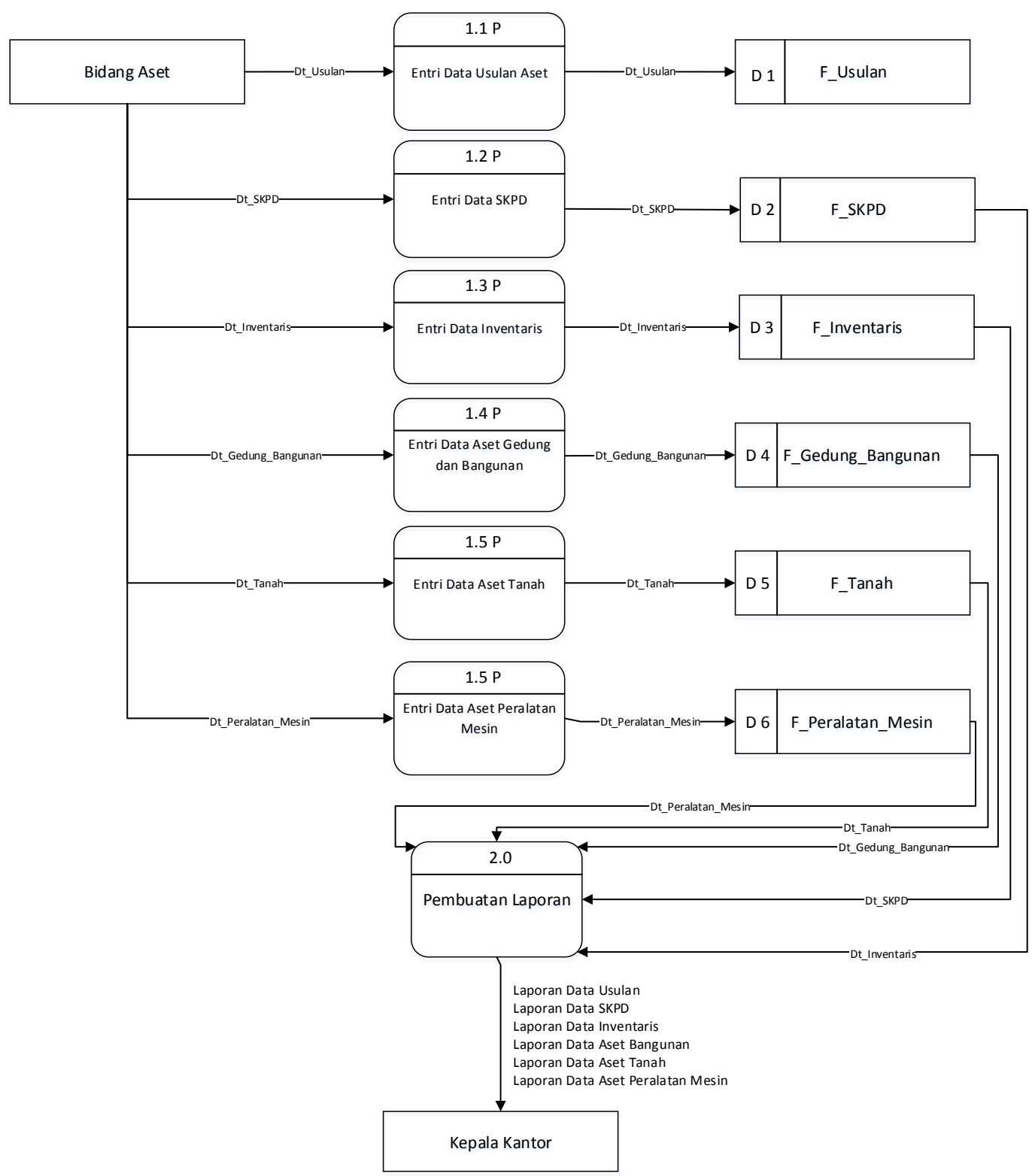

Fig.7. Data flow diagram level 0 system design

Based on Figure 7, it can be explained that the process of collecting assets. The Asset Sector conducts asset data collection, wherein each asset data has its own category, then based on the data that has been inputted, the Head of Office verifies the asset data so that the data will be stored and published on the system. The process of assets will be continued with the preparation of asset reports and will be reported periodically to the Head of the Department. 


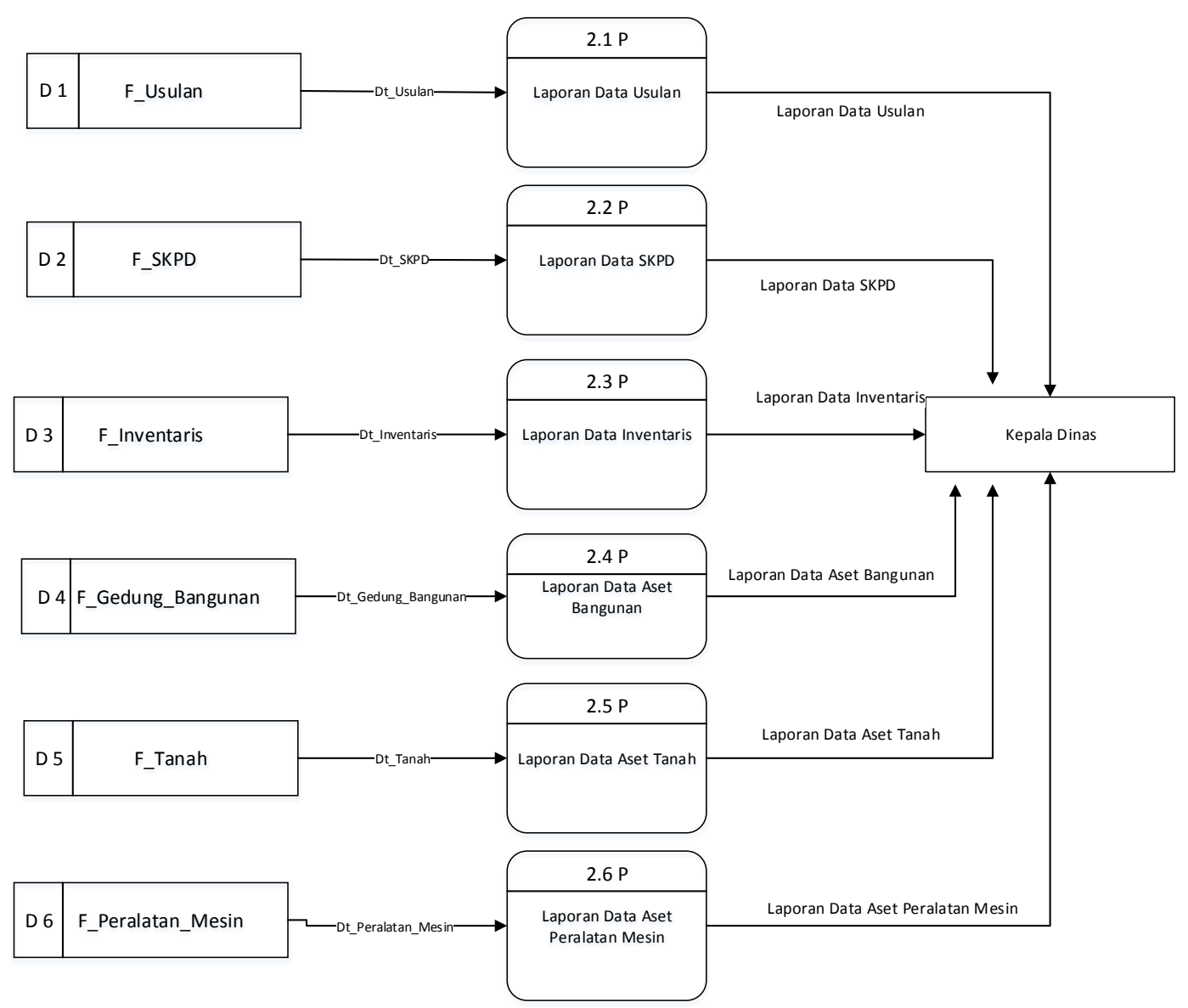

Fig.8. Data flow diagram level 1 process number 2 system design

Based on Figure 8, it can be stated that each data file provides data to the report-making process, from each report-making process to give each report to the admin section, the process of making Asset data. Testing the verification system to test all elements of the software elements that are made whether they are as expected. Software testing in this study is carried out by the user or the user, while the testing method used is the testing box. Black box testing is testing the basic aspects of the system without paying attention to the logic structure of the software. This method is used to see if the software is functioning properly. Black box testing is a method of designing test data that is based on the specifications of the software being made. The things that will be tested using the black box method are as follows:

\begin{tabular}{ll}
\multicolumn{2}{c}{ Table 1. Asset Data Collection Information System Testing Plan } \\
\hline \multicolumn{2}{c}{ Requirement } \\
\hline Login & \multicolumn{1}{c}{ Test Items } \\
User Data & Login \\
SKPD Room Data & Adding User or User Data \\
Inventory Data & Adding Room Data / SKPD \\
Building / Building KIB Data & Adding Inventory Data \\
Land KIB data & Adding KIB Data for Buildings / Buildings \\
Equipment / Machinery KIB data & Adding Land KIB Data \\
Asset Proposed Data & Adding Equipment / Machine Data \\
\hline
\end{tabular}

\section{Result and Discussion}

The design of the asset management information system software at the Aceh Provincial Plantation Office which the author designed consists of several stages, namely input design, output design, process design, control design, workforce design, and cost design. The authors hope that this design will make it easier for each user, especially the assets section of the Aceh Provincial Plantation Service. For more details on the design stages, it can be seen in the following explanation. In this input design consists of several program files, namely:
a) Room Data Entry Program

b) Proposed Data Entry Program 
c) Building and Building Asset Inventory Card Data Entry Program (KIB)

d) Goods Inventory Card (KIB) Data Entry Program for Equipment and Machinery Assets

e) Land Asset Inventory Card Data Entry Program (KIB), and

f) User Data Entry Program.

The design output of the sales process design system at the Aceh Provincial Plantation Office consists of several program outputs, namely:

a) Recap Room Data

b) Recap of Proposed Data

c) Inventory Recap

d) Building and Building Asset Inventory Card (KIB) Report

e) Report on KIB per Building and Building Asset

f) Equipment and Machinery Asset Inventory Card Report (KIB)

g) Report on KIB per Equipment and Machinery Asset

h) Land Asset Inventory Card (KIB) Report

i) Report on KIB per Land Asset

j) List of Rooms

k) Proposal List

1) Inventory List

m) List of KIB Building and Building Assets

n) List of KIB of Equipment and Machinery Assets

o) List of KIB Land Assets, and

p) User list

The use of the Design of the Asset Management Information System in the Plantation Office of Aceh Province, seen from the design of the application in the form of an application display. The login form is used as system security from abuse of access rights, so that data security can be guaranteed. Here the user is asked to enter a user name and password to be able to access further data. For more details, the login process can be seen in the image below.

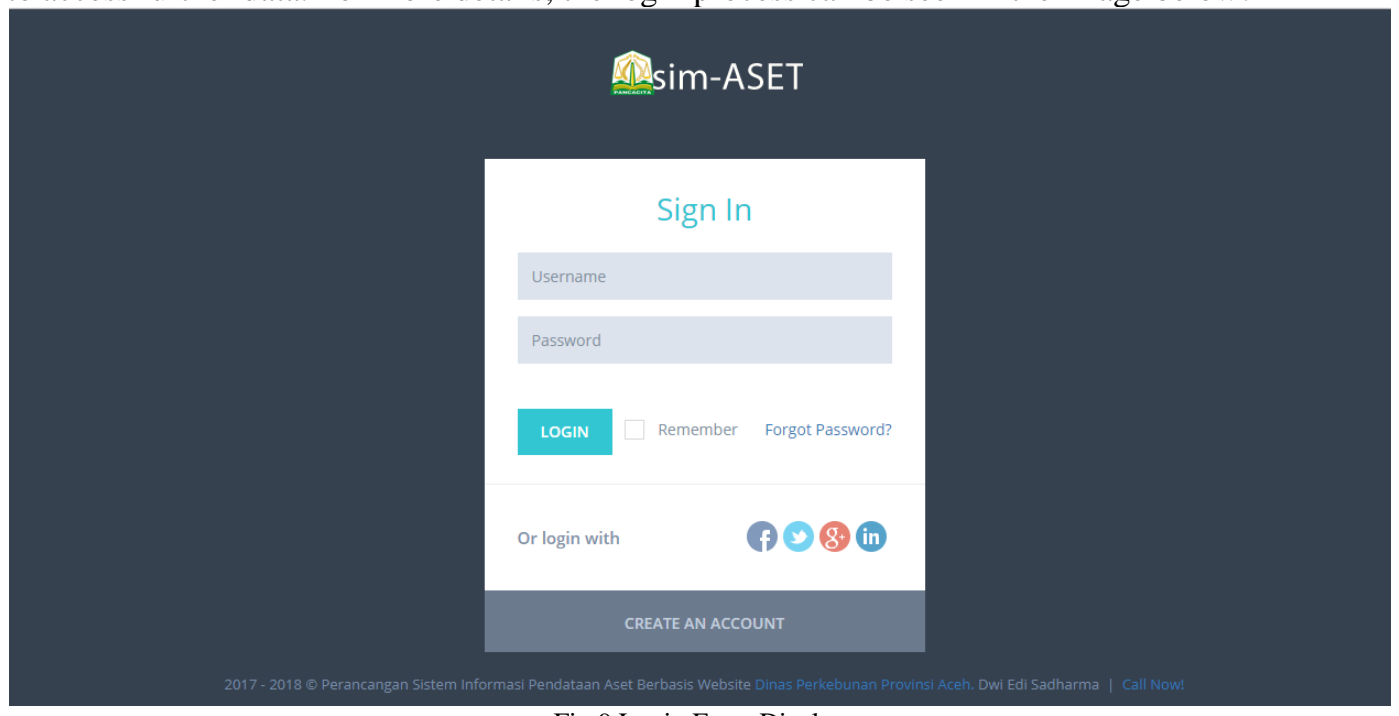

Fig.9 Login Form Display

In the form below is the main menu form which contains the display of the master user, space, proposal, inventory, KIB of building and building assets, KIB of equipment and machinery assets, KIB of land assets, and user. Computer users just need to click the desired menu icon to see what is in the file. 


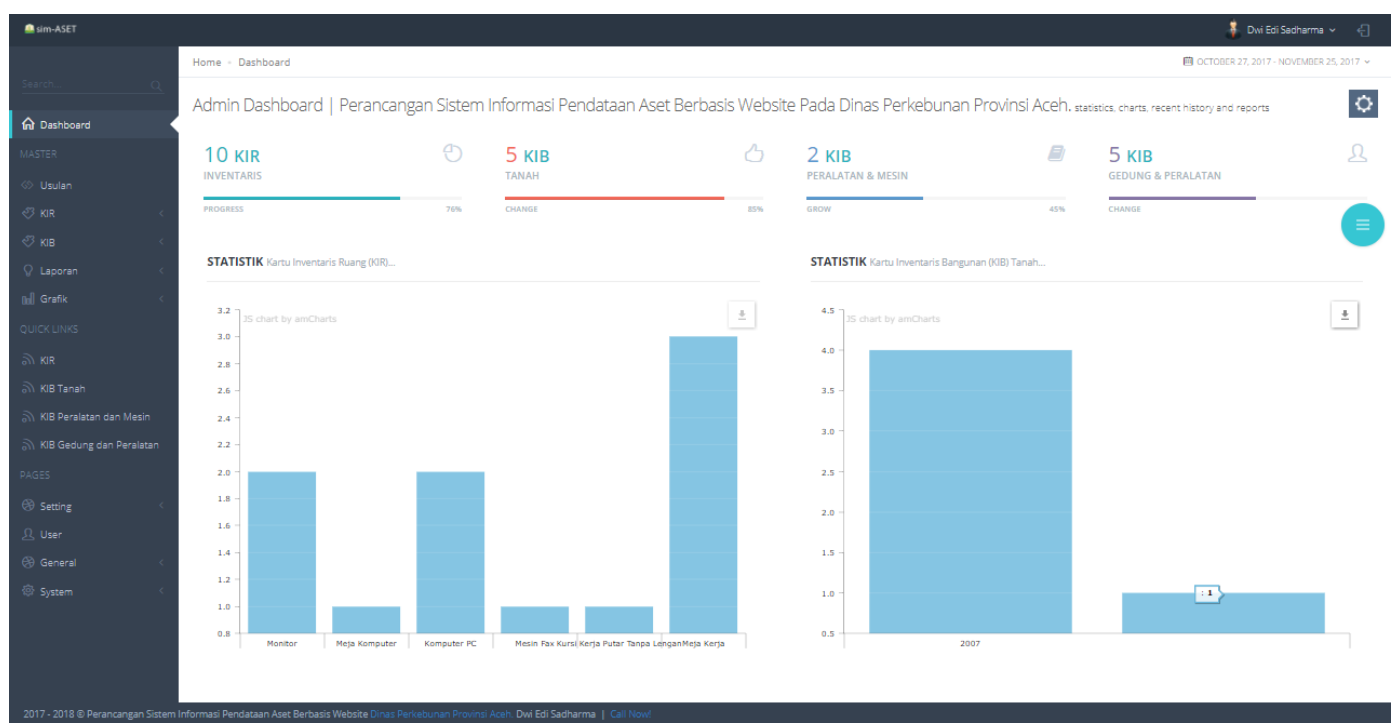

Fig.10. Main Menu Display

The user input menu is a page where the user can input user data for the application system. The user form serves to provide access to the system.

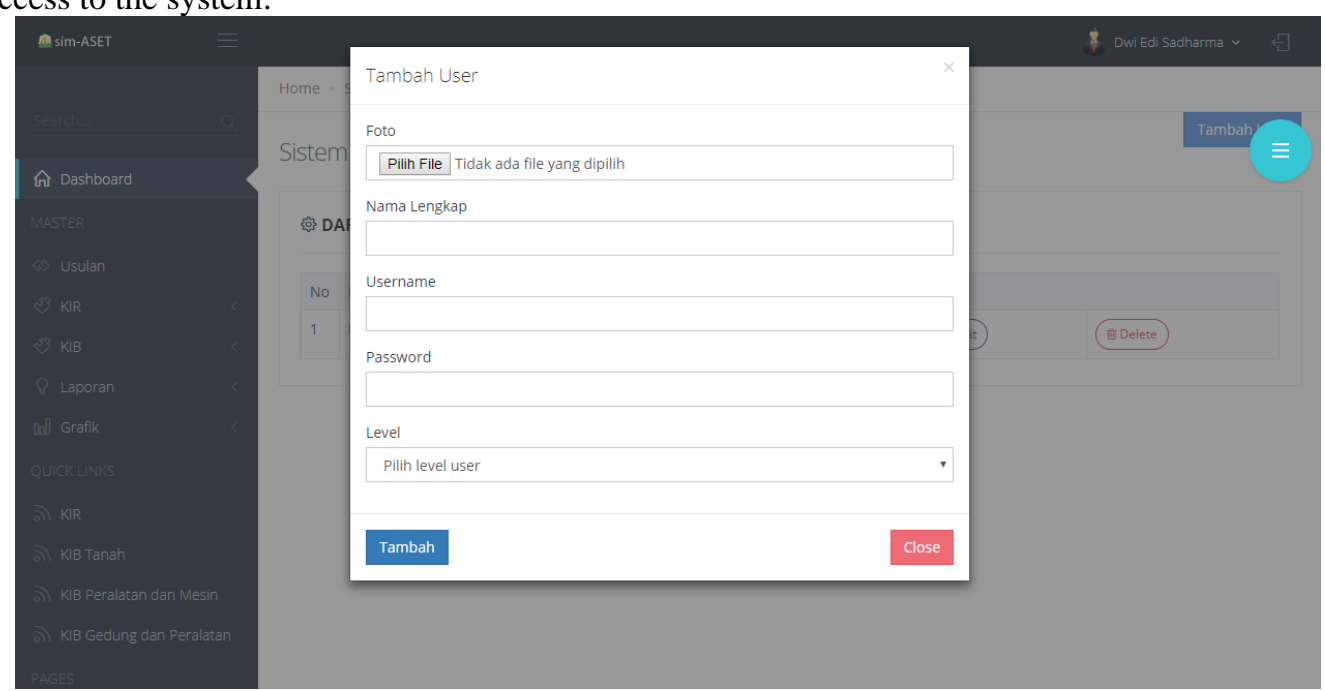

Fig.11. Input User

The results of data input will be displayed in the form of a list consisting of a photo, full name, username, password and level as shown in the image below.

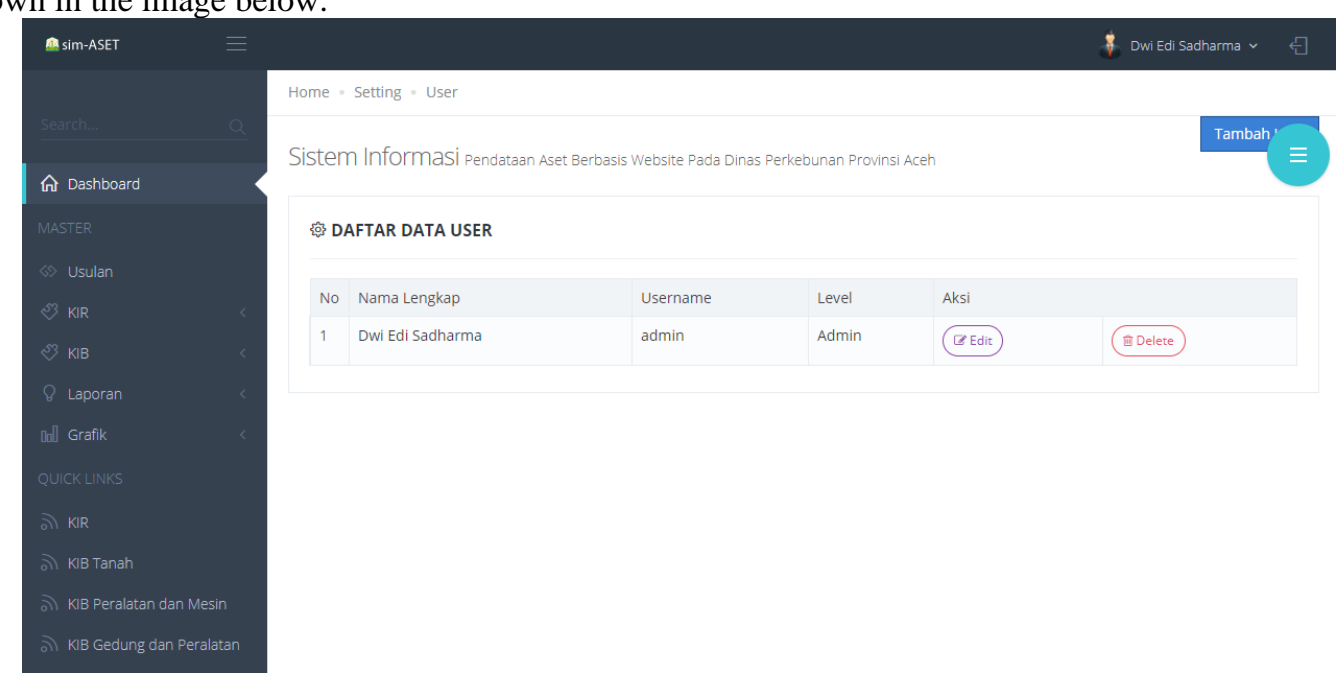

Fig.12. User List 
The room input menu is a page where the user can input room data. Where in it contains the code, room name, and description.

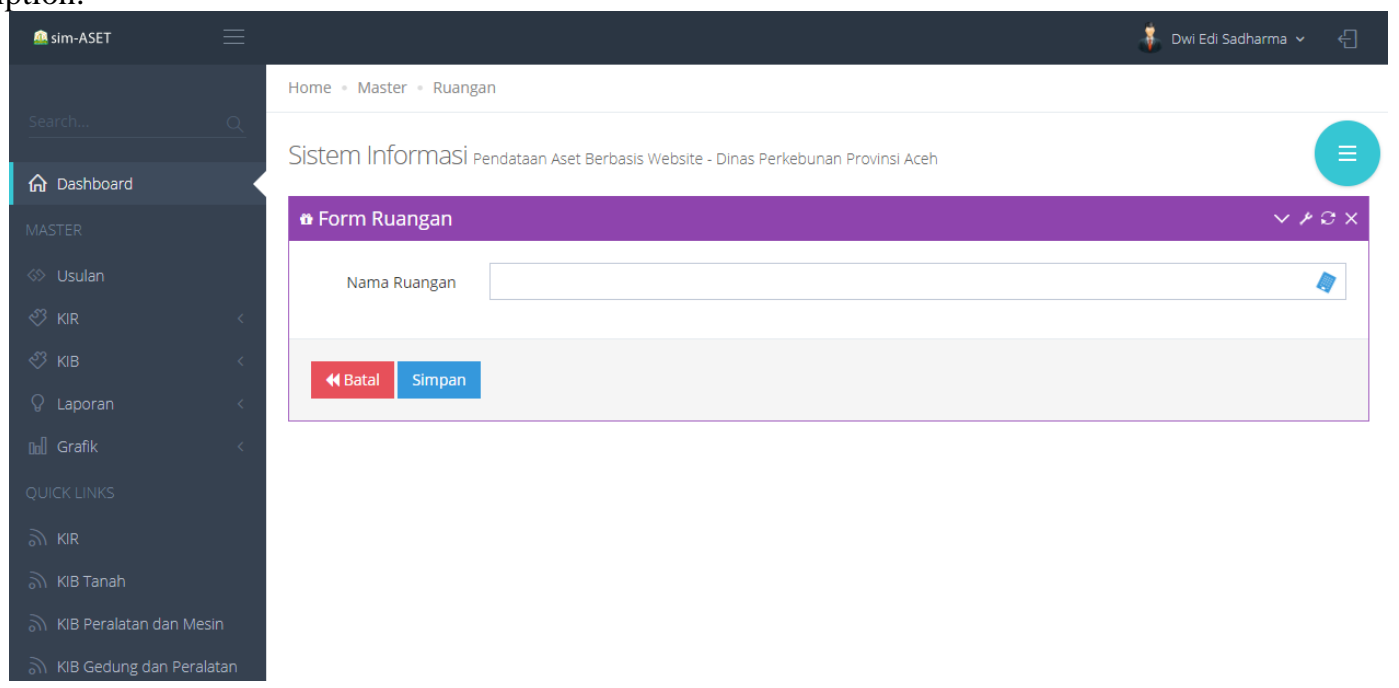

Fig.13. Space Input

Each added space data will be displayed in the form of a list, the room list form also functions to manipulate room data such as adding, changing space data and deleting space data, as in Figure 14 below.

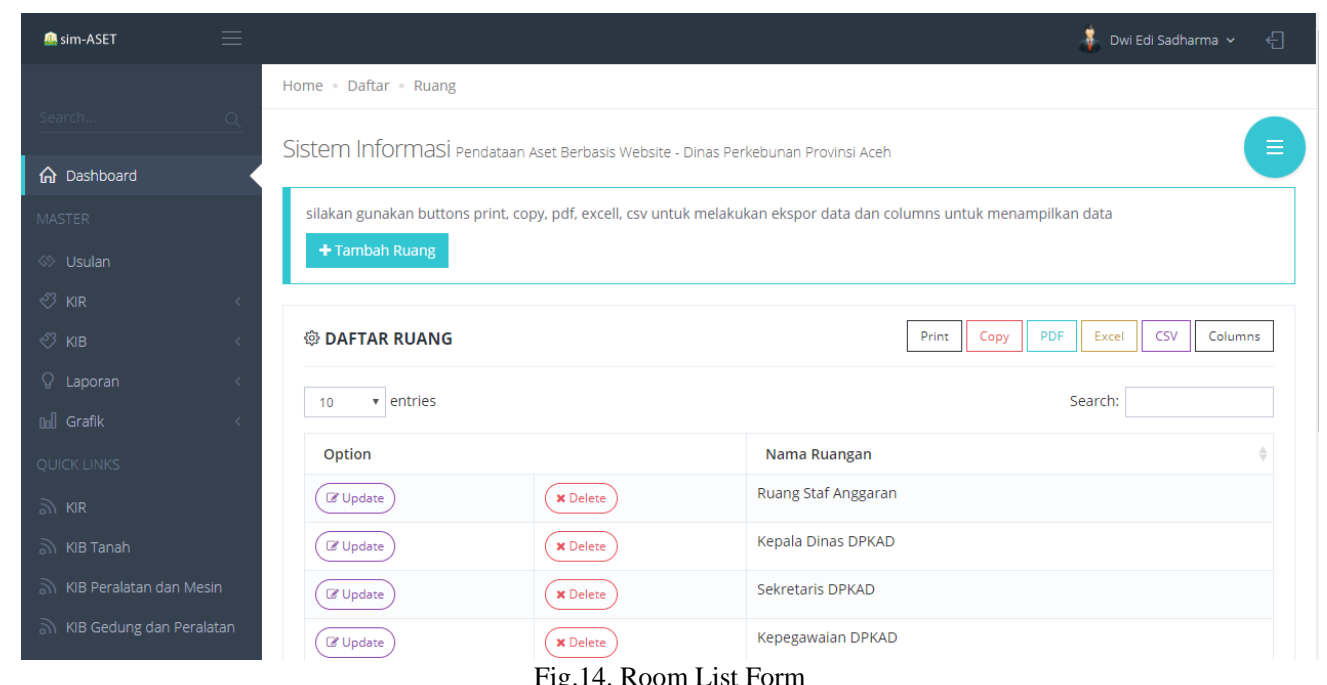

Fig.14. Room List Form

In addition to the room list form, the results of the room report consist of detailed room data and a room data recap report as shown in Figures 15 and 16 below. 


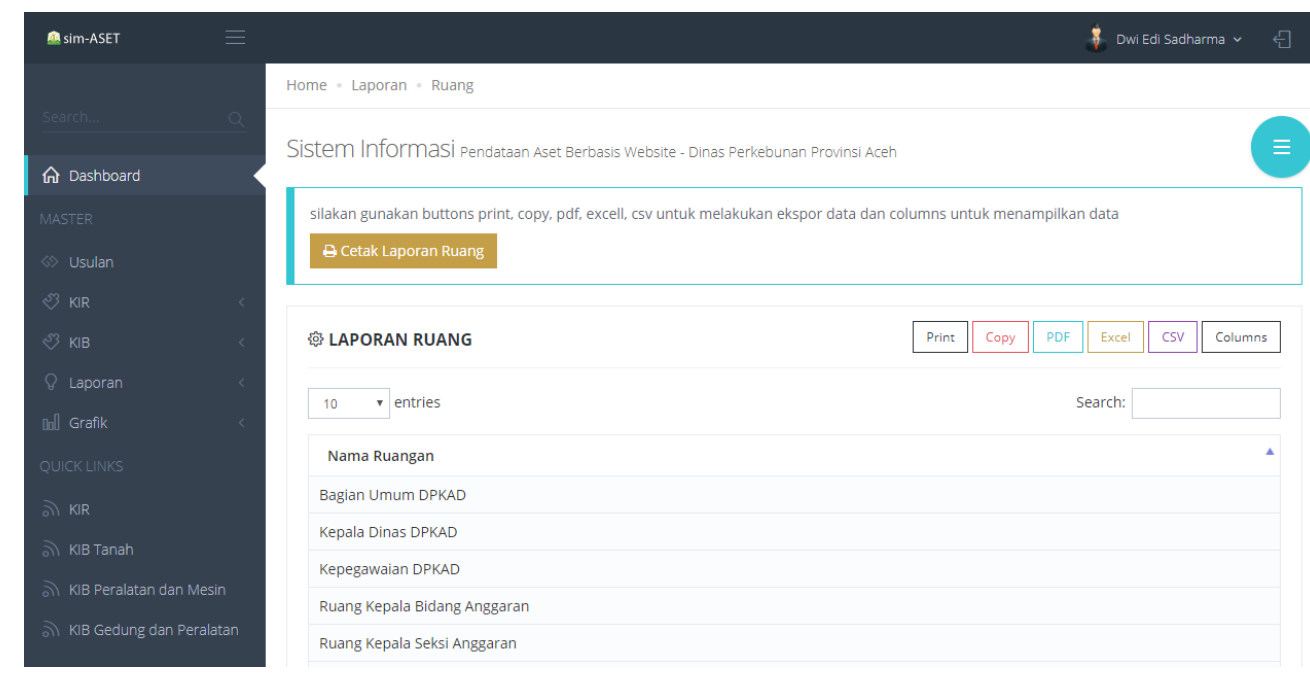

Fig.15. Room Data Detail Report

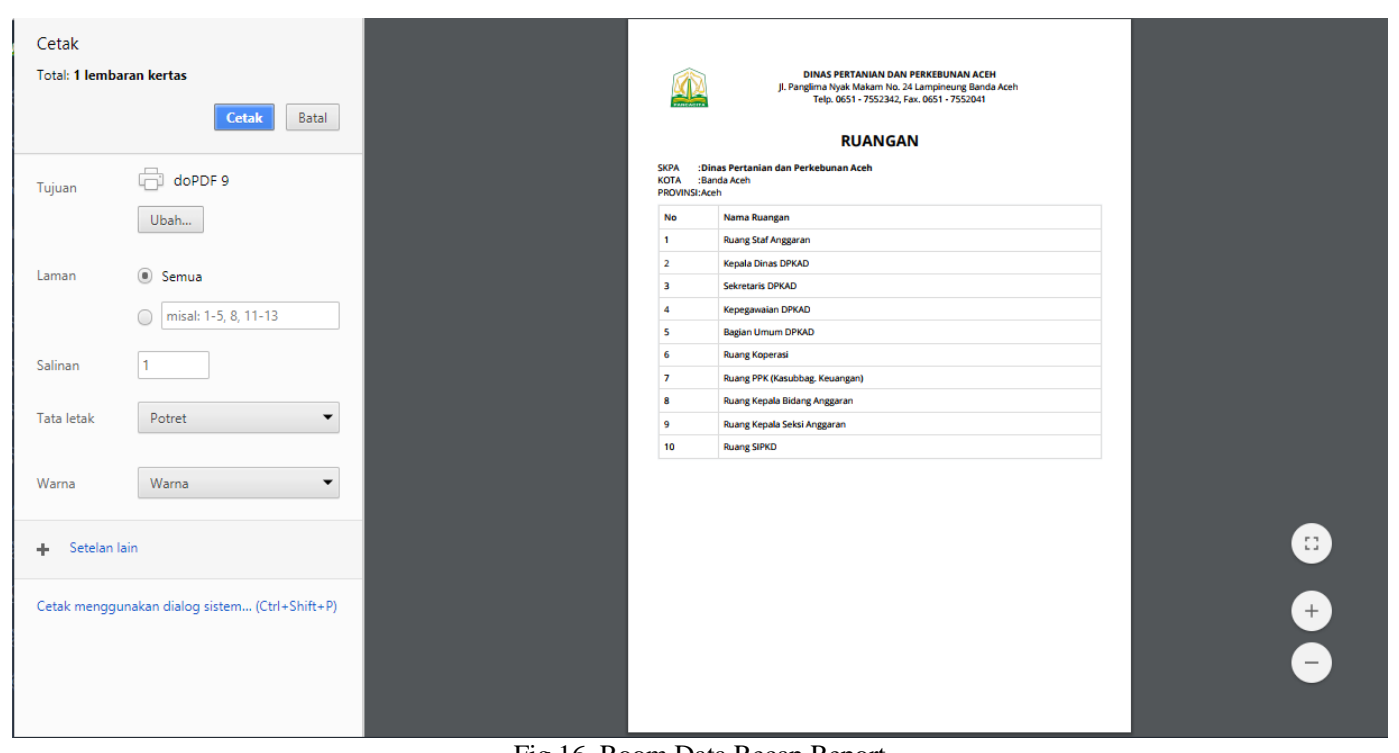

Fig.16. Room Data Recap Report

The item proposal data input menu is a page where the user can see a number of item proposal data for adding service inventory to the system.

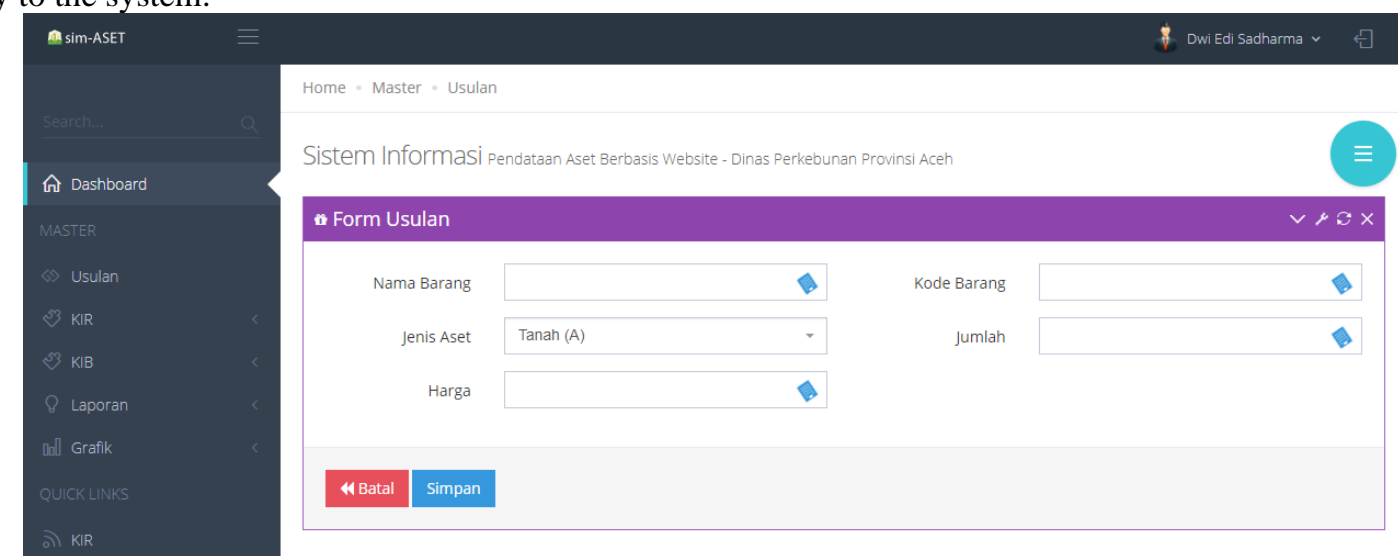

Fig.17. Proposed Data Input Form

After the data is added or stored, the results of the proposed data will also be displayed on the proposal list form, which functions as adding, changing, and deleting the proposed data. So that the results of recording the proposed item data will also produce a detailed report on the proposed goods and a recap of the proposed goods as in Figures 18, 19 and 20 below. 


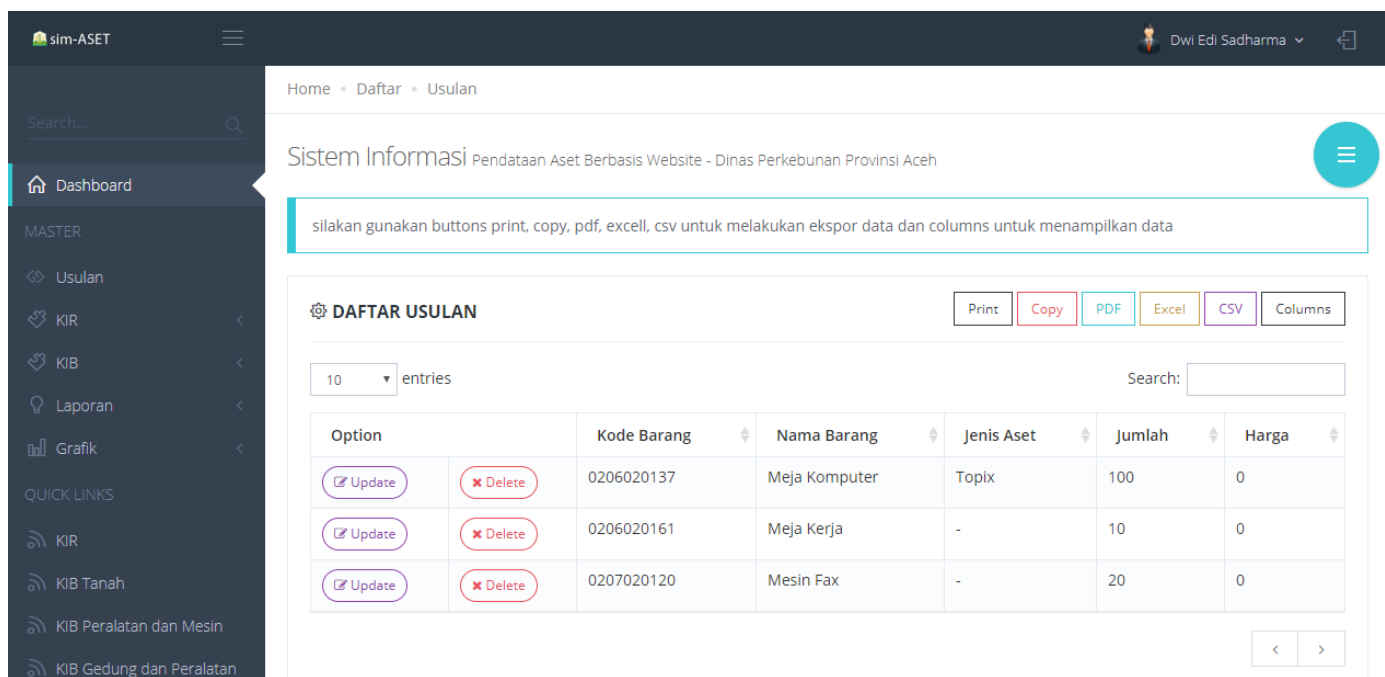

Fig.18. Proposed Data List Form

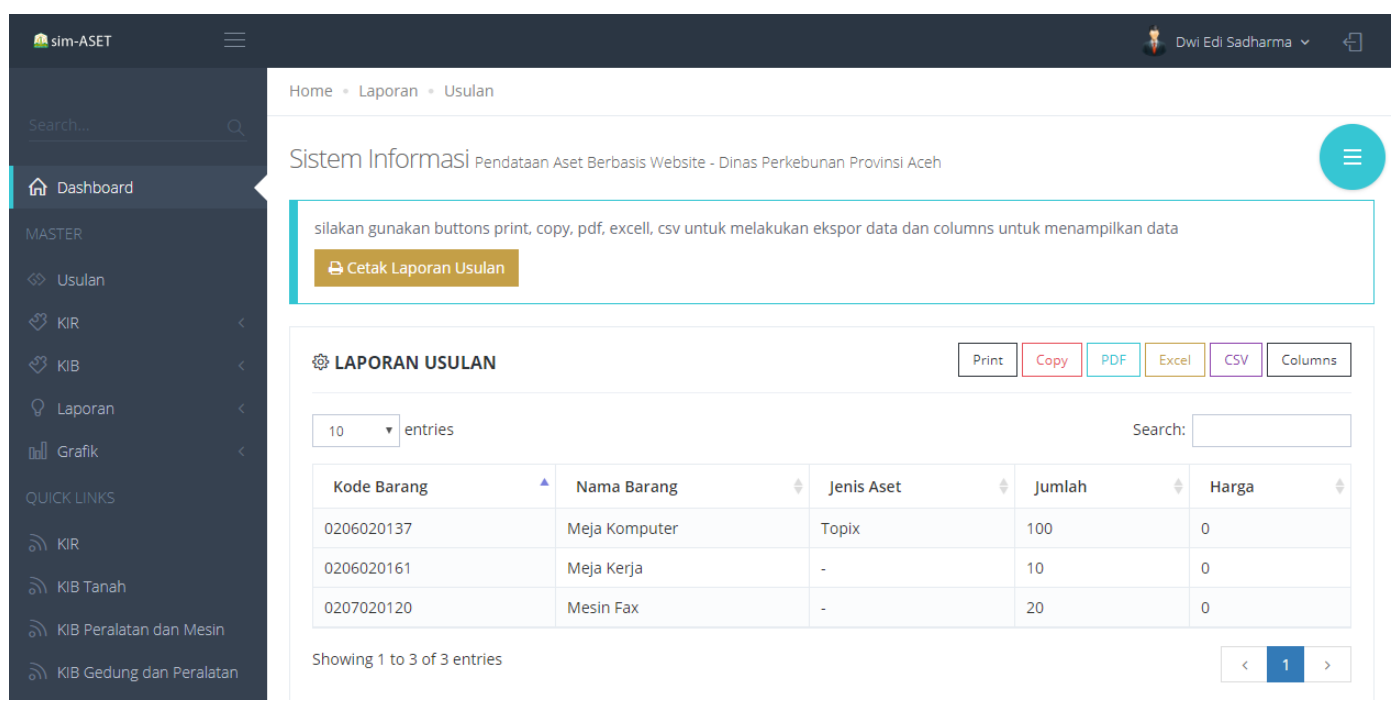

Fig.19. Proposed Data Detail Report

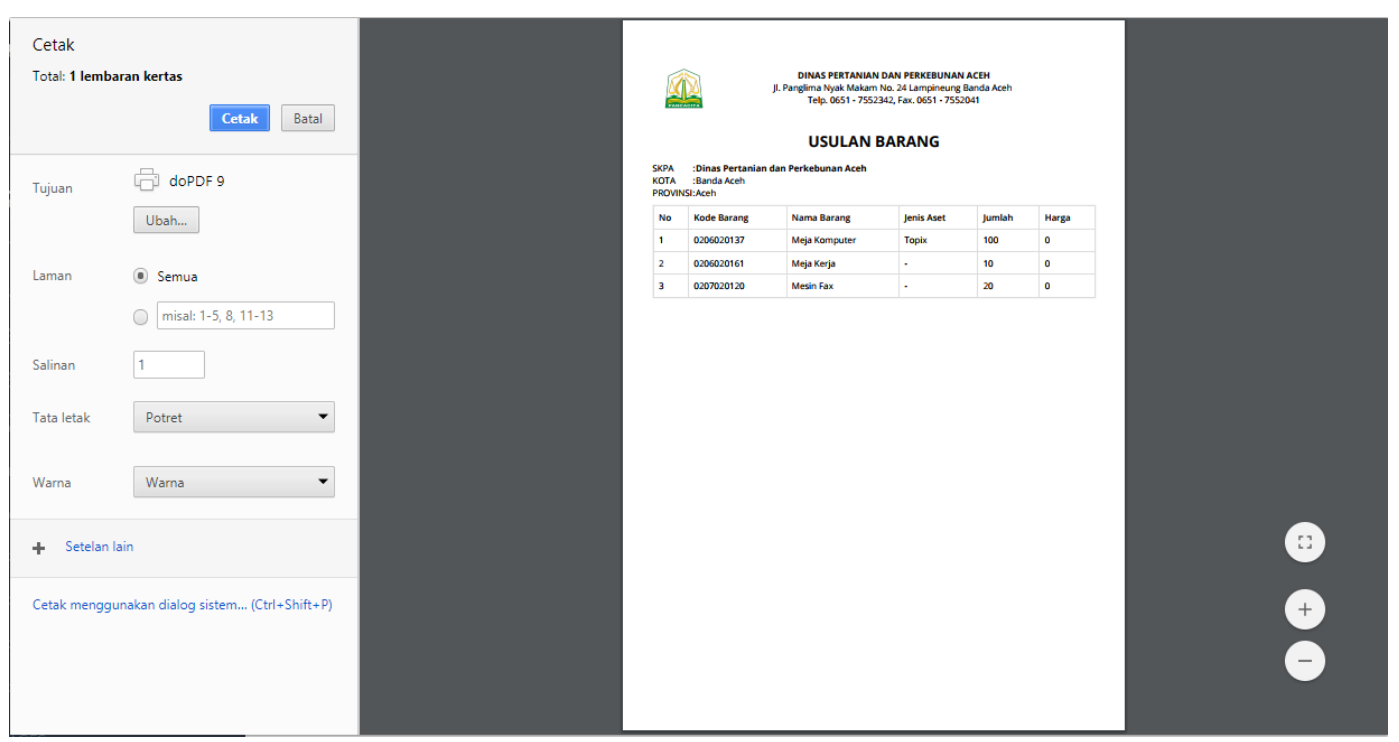

Fig.20. Proposed Data Recap Report 


\section{Conclusion}

The conclusion that can be obtained from the analysis and design of the Asset Management Information System is that this information system will be used to process asset data at the Aceh Provincial Plantation Office, namely adding, editing, and searching for asset data. This system will also be equipped with displaying reports such as asset data reports and others. This application can be used as an alternative tool in processing asset data in the Aceh Provincial Plantation Office.

\section{References}

[1] Rusdiana, A., Moch Irfan, and Moch Irfan. "Sistem informasi manajemen." (2014).

[2] Ahmad, Lukman. Buku Referensi: Sistem Informasi Manajemen. Vol. 1. KITA Publisher, 2018.

[3] Martin, William J. The global information society. Taylor \& Francis, 2017.

[4] Drahos, Peter. "Information feudalism in the information society." The Information Society 11.3 (1995): 209-222.

[5] Awalia, Bella. "Keamanan Informasi." Jakarta: Universitas Mercu Buana (2018).

[6] Maulidia, Nia, Siti Rochimah, and Achmad Affandi. "Pengembangan Prosedur untuk Optimalisasi Kualitas Sistem \& Layanan Jaringan TIK dengan COBIT4. 1 dan ITIL. V3." Prosiding Seminar Nasional Manajemen Teknologi XVII Program Studi MMTITS, Februari. 2013.

[7] Mukhtar, M., and I. Ismail. "The use of Certainty Factor (CF) in Technostress Diagnation Expert System." International Journal of Innovative Science and Research Technology (IJISRT) 4.5 (2019): 727-732.

[8] Nasir, Nasir. Dampak Sikap dan Norma Subyektif Terhadap Niat Beli Mahasiswa Sebagai Konsumen Potensial Produk Nokia" Jurnal Manajemen dan Bisnis 11.1 (2011).

[9] Amri, Khairul. "Pengaruh kemampuan kerja, komunikasi, kekompakkan tim kerja dan kepemimpinan terhadap kualitas laporan hasil pemeriksaan Inspektorat Aceh." Jurnal Ilmiah Manajemen Muhammadiyah Aceh 2.2 (2012).

[10] Bahruni, Bahruni, and Fathurrahmad Fathurrahmad. "Data Mining Analysis: Research Topics Trend on Web of Science, SINTA, and Student Final Assignment at AMIK Indonesia." International Journal of Latest Engineering and Management Research (IJLEMR) 4.5 (2019): 99-107.

[11] Yunita, Irma, and Joni Devitra. "Analisis Dan Perancangan Sistem Informasi Manajemen Aset Pada Smk Negeri 4 Kota Jambi." Jurnal Manajemen Sistem Informasi 2.1 (2017): 278-294.

[12] DIMAS, MUHAMMAD, Saut Parulian Panjaitan, and Abu Nawar Basyeban. PROSEDUR DAN PERSYARATAN PENGHAPUSAN BARANG BERGERAK MILIK NEGARA/DAERAH YANG KADALUARSA MENURUT PERATURAN PEMERINTAH NOMOR 27 TAHUN 2014 TENTANG PENGELOLAAN BARANG MILIK NEGARA/DAERAH. Diss. Sriwijaya University, 2018.

[13] Mahpud, Mahpud. "Perancangan Aplikasi Monitoring Data Aset Dan Inventaris IT Berbasis Web Pada PT. TMS Logistics." Jurnal Teknik 4.1 (2017).

[14] Wali, M. "Modul Praktikum Rekayasa Perangkat Lunak." (2020).

[15] Iqbal, Taufiq, Daniel Aprizal, and Muhammad Wali. "Aplikasi Manajemen Persediaan Barang Berbasis Economic Order Quantity (EOQ)." Jurnal JTIK (Jurnal Teknologi Informasi dan Komunikasi) 1.1 (2017): 48-60.

[16] Kadafi, Muhammad. "SISTEM INFORMASI PENGOLAHAN DATA TRANSAKSI PADA CV. GLOBAL TRANS SOLUTIONS." Jurnal Indonesia: Manajemen Informatika dan Komunikasi 1.1 (2020): 1-8. 